Vol 4 Number 2

ISSN: 2407-0742

\title{
IMPROVING STUDENTS' WRITING SKILL BY USING SCAFFOLDING TECHNIQUE TO THE SEVENTH GRADERS OF SMP BOPKRI GODEAN
}

\author{
Rika Rimawati ${ }^{1}$, Hermayawati ${ }^{2}$ \\ English Education Departement, Faculty of Teacher Training and Education \\ Mercu Buana University of Yogyakarta \\ $\underline{{ }^{1} \text { rikarimawatiumby@gmail.com, }}$ h. hermayawati@yahoo.com
}

\begin{abstract}
The background of the study was based on the phenomenon at the seventh graders of the SMP BOPRI Godean. Learning English especially writing skill were still low in mastering vocabulary, sentence structure, and paragraph organizing. The research aimed (1) to analyze the students' writing by using scaffolding technique; (2) to describe the improvement of the students' writing skill by using scaffolding technique; and (3) to find out the students' interests in writing skill by using scaffolding technique. To solve the problem, the researcher conducted Classroom Action Research and applied scaffolding technique in teaching English to improve student's ability in writing skill. The participants of this research were the 14 students of the seventh graders of SMP BOPKRI Godean. In this study, the researcher conducted a scaffolding technique of teaching writing descriptive text in three cycles by using scaffolding model adapted from Silvia Read. The five steps in scaffolding technique by Silvia Read were inquiry, modeling, shared, collaborative, and independent. The researcherexpected that the students could improve their writing skill by using the scaffolding technique and interested in English writing skill. The result of this study was showed by pre-test and post-test. In pre-test, the students' average score was 49 , whereas in the students' post-test cycle one, the students' average score was 64 . In the second cycle, the students' average score was 75.9. Finally, the researcher could conclude that the result of this research showed an improvement of the students' writing skills by using scaffolding technique.
\end{abstract}

Keywords : Witing, Scaffolding Technique, Adolescents, CAR.

\section{A. INTRODUCTION}

English is a very important language in this current era. Many people in all over the world use English as their second language. Indonesia puts English as the first foreign language which is important for education, science and technology, art and culture, and establishing international relationship. In learning 
English, there are four language skills should be learnt. There are listening, reading, speaking, and writing. Therefore, writing is considered as an important skill to be learnt. Teachers of English should teach writing equally and appropriately as the way they teach other skills.

Writing skill is rather difficult to be master. The students had learnt on how to have a good writing, but they still find difficulties. According to Harmer (2004, p.3), if spoken language can be naturally acquired because children (as learners) are exposed to it, the ability to write has to be consciously learned. While students learn writing, they need time and a teacher to teach them. Spratt, Pulverness, and Williams (2005) also states that time is needed because writing involves a number of stages such as brainstorming, making notes, planning, writing a draft, editing, and proof-reading.

The other skills are compiling in writing skill because the student who has already had good writing skill usually has good ability in the other skills. Writing also has the complex rules according to the kinds of writing. Writing as a process to get product that will influence by some elements such as vocabularies, grammar, organization, spelling, and punctuation. According to Graham (2007), the leaning of writing skill in the schools has two benefits that very important. The first is writing skill can show the ability in using strategy such as planning, evaluating and revising for achieve the writing purpose and the second is writing cand improve the students knowledge.

Many Indonesian students, especially junior high school students have difficulties in mastering the four language skills especially in writing skill. In this study, the researcher will be observing students' problem in writing ability. Therefore, Alwasilah (2005:6) declares apparently as a whole, the Indonesian high school students do not have strong basic to write academically, since the national education in Indonesia does not provide the students sufficient writing skill and critical thinking skill. Maslakhah (2005:21-28) also states that the difficulties of writing are not only from the students themselves like their characters, mentality, and personality, but also from the outside of the students like how to find the topic, to arrange the sentence effectively, and to master the rule in writing.

According to Brown (2001: 335), writing is the written products of thinking, drafting, and revising that require specialized skills on how to generate ideas, how to organize them coherently, how to use discourse markers and rhetorical conventions coherently into a written text, how to revise text for clearer averaging and how to edit text for appropriate grammar and how to produce a final products.

Writing is used extensively in higher education. If students do not understand on how to express themselves in writing; they will not be able to communicate well with teacher, lecturers, professors, employers, peers, or just about anyone else. Much of professional communication conducted in writing: proposals, memos, reports, applications, preliminary interviews, e-mails, and more are part of the daily life of a college student or successful graduate. Even if students manage to learn the material in their writing task without knowing how to write well, they will not be able to express their feeling or share their knowledge to the people who are making the big decisions.

Based on the early observation, the researcher found the problems of writing skill at SMP BOPKRI Godean. The researcher gathered the information during the classroom observation on August 10 2016. She found the problem related to the student's writing skill. From the observation, students cannot reach score target. It was because the students had very low skills in choosing vocabularies, sentence structure, and paragraph organizing. The school applies 2013 curriculum with the minimum criteria completeness or 
KKM (Kriteria Ketuntasan Minimal) is 67 for the indicator of writing skill. In fact, their writing ability was still under the minimum criteria completeness. The average pre-test' score of fourteen students of seventh grade at SMP BOPKRI is 49, so they could not reach the score target. Besides, the teacher's techniques was not interesting for the students and not encouraged them in writing. The teacher still gives instruction to the student to write a certain topic after that collect it.

Based on the appeared problems, it is necessary for the researcher to improve the students' writing skill especially for the seventh grades by using scaffolding techniques. Because one of the main benefits of scaffold instruction is providing a supportive learning environment. According to Olson \& Pratt, (2000) the scaffolding instruction is more knowledgeable other provides scaffolds or supports to facilitate the learner's development. The scaffolds give facilitate to the student's ability to build the prior knowledge and internalize the new information. The activities provided in scaffolding instruction are exceeded the level of what the learner can do alone. Educators may also use questions as scaffolds to help students in solving a problem and complete a task. The teachers may increase the level of questioning or specificity until the student is capable to provide a correct response.

In a scaffold learning environment, students are free to ask questions, provide feedback, and support their peers in learning new material. When the teacher incorporates scaffolding in the classroom, he/she become more of a mentor and facilitator of knowledge rather than the dominant content expert. This teaching technique provides the support for students to take a more active role in their own learning. Students share the responsibility of teaching and learning through scaffolds that require them to move beyond their current skill and knowledge levels. Through this interaction, students are able to take ownership of the learning event. Vigotsky (1978) also states that the scaffolding technique makes the learning process more tractable for the students with the changing complex and difficult task in ways that make the tasks accessible, manageable, and within student's zone of proximal development. It averages that by scaffolding technique, can inspire the students to want to learn more and increase their knowledge and understanding. In this technique, the teacher provide scaffold and support the students to complete the task and facilitate their learning.

\section{B. METHOD}

Technique is a procedure or skill for completing a specific task. In teaching, there were some techniques actions that teachers could use to achieve certain goals in the classroom. These were among others of teaching techniques such as Experience, Generalization, Reinforcement and Application (EGRA) technique; Present, Practice, and Produce (PPP) technique; Engage, Study, Activate (ESA) technique; clustering technique; mind mapping technique; Total Physiscal response(TPR) technique; and scaffolding technique. From those techniques, the researcher chose to apply the scaffolding technique as the authentic technique for the students grade VII, because by using this technique the students can independently will try to find out the information from the teacher and pass some phases in learning writing. Beside that the students will be motivated their learning process.

According to (Raymond, 2000, p.176), scaffolding instruction was an originate strategy of teaching from Lev Vygotsky's sociocultural theory and his concept of the Zone of Proximal Development (ZPD). The zone of proximal development was the distance between what the students could do by themselves 
and in the next of the learning, they can achieve with competent assistance. Raymond (2000) also stated that scaffolding instruction as the role of the teachers and others in supporting the learner's development and providing support structures to get to that next stage or level. A rich experience was what leaner needs to develop to a knowledgeable individuals and the impact of the surrounding environment and the scaffolds in it are important for learning.

In the education, scaffolding refered to the variety the techniques of instructional that use to move the students progressively toward the stronger understanding and, the ultimately, the greater independence in their learning process. The term by itself offered the relevant descriptive metaphor: the teachers provided succeeding levels of the temporary support, which, helped the students to reach higher levels of the comprehension, and the skill acquisition that they would not be able to achieve without a help. According to Sawyer (2006), instructional scaffolding was a learning process that designed to encourage a deeper level of the learning. Scaffolding is the support during the learning process, which is appropriate to the needs of the student with the aim of helping the student achieve his/her learning goal.

Scaffolding is the essential element of effective teaching, and all teachers to a superior certainly use the various forms of instructional scaffolding in their teaching process. The scaffolding used to bridge in learning gaps. The difference between what the students have learned and what they were expected to know and be able to do at a certain point in their education. For example, if students are not at the writing level required to understand a text being taught in a course, the teacher capacity use instructional scaffolding to increasingly improve their reading ability until they can read the required text independently and without the teacher's help. The goals of scaffolding is to reduce the negative emotions and self-perceptions that the students possibly will practice when they get frustrated, intimidated, or discouraged when attempting a difficult task without a help, direction, or understanding what they need to complete it.

Vygotsky (1978) has proposed that the learner needs to be scaffold in order to acquire all the skills that would have been difficult to acquire independently. The Vygotskian theoretical perspective holds that learners and especially children can perform more challenging tasks when assisted, and that they can reach a high level of development (Zone of Proximal Development).

According to Vygotsky, there were two aspects of the learning development; the "actual development" and the "potential development" (Vygotsky, 1978, p. 86). The Zone of Proximal Development (ZPD) is the area between what the learners can achieve by themselves, and what they can attain with the help of more knowledgeable individuals. As a result, the meaningful learning is enhancing in the learner's ZPD, with the use of all the available scaffolds afforded by the surrounding environment.

According to Sylivia Read (2010), the scaffolding in writing has some steps, the steps are follow:

a. Inquiry, in this step the researcher integrated reading and writing instruction also focus on a particular genre and engaged the students' features of that genre.

b. Modeling, after the students could know the instruction well. Then, the researcher modeled how to write. She introduced some stages in writing processes.

c. Shared, in the third phase the students could share what they are going to write. They engage in making decision about topic, the sentence of structure and organize the writing 
d. Collaborative, after reaching all stages in writing processes, the students will ask to have a collaborative in writing process. Two students work together to produce writing.

e. Independent, it is the last phase. After reaching all of the phases the students have to write their final writing.

Jamie McKenzie (2000) suggests that there are eight characteristics of scaffolding instruction. In order to engage in scaffolding effectively, teachers. Those characteristics are: (1) providing clear direction; (2) clarifying purpose; (3) keeping students on task; (4) offering assessment to clarify expectations; (5) pointing students to worthy sources; (6) reducing uncertainty, surprise and disappointment; (7) delivering efficiency; (8) and creating momentum.

This research would be conducted to find out the significant effect in writing descriptive text by using scaffolding technique for the seventh grade's student of Junior High School. Based on the theories above could be concluded that the scaffolding technique in teaching able in facilitating and gaining the students in finishing their writing assignment.

In this research, the researcher conducted a scaffolding technique of teaching writing descriptive text in three cycles. The researcher also would like to use scaffolding model by Silvya Read. There are five steps in scaffolding technique. They are inquiry, modeling, shared, collaborative and independent. In inquiry step, the researcher asked the students to find out the information about Indonesian heroes or International figures shown by researcher. The picture would be described by the students. Then she would give a list of adjective words as a clue and gives a model to the students, how to write an appropriate writing and make a point that they should pass some steps in writing. After understanding the teacher's explanation and knowing what they were going to do,the students share their works to the teacher then make outline and a rough draft of the outline.

Having reached all stages as mentioned above, they would be asked to write the description related to the shown picture collaboratively. They would also be asked to analyze each of their pair works. After the students have finished their writing independently, finally the students were asked by the researcher to revise their writing and their final writing that would be as post-test.

\section{FINDING AND DISCUSSION}

The observation during the process of teaching learning was conducted on $10^{\text {th }}$ Augustus 2016. From the observation, the researcher found that the students have the difficulties in writing skill and they had less motivation in writing skill. Besides, the researcher also found that the teacher's technique was not interesting and effective for the students. It meant that the students needed a new teaching technique that was effective and could give the support the students during the learning process. Those information was important for the writer to give treatments in cycles.

The pre questionnaire was conducted to know the students' response about English lesson especially in writing skill. The questionnaire was given to the seventh grade students of SMP BOPKRI Godean on August $9^{\text {th }}$ 2016. The questions had ten questions. 
Based on the students' answers of pre questioners the researcher interpreted that $65.71 \%$ of the students felt difficult and not interested in writing English. It means that they need the new teaching technique that effective and can give the support the students during the learning process.

The conclusion from the interview, observation and the questionnaire of the seventh graders students of SMP BOPKRI Godean had the problem of writing skill in mastering vocabulary, sentence structure and paragraph organizing.

Based on the result of the pre-test, the data showed that the average score of the pre-test was 49. There were only two students who achieved the minimum criteria completeness (Kriteria Ketuntasan Minimal) 67 (eighty seven)average while 12 students were under criterion. From the researcher analyzing, it could be seen that almost of the seventh grade students of SMP BOPKRI Godean their writing skill was still very low.

From the analyzing of pre-test, the researcher concludes that most of the seventh graders students of SMP BOPKRI Godean had difficulties in writing skill. So, it need the solution or strategy to overcome the problems. The researcher used the scaffolding technique as an innovation in teaching learning process of writing. The action very needed to improve the students' ability in their writing skill. In this research, the action research was conducted in two cycles and the every cycle involved four stages there are planning, acting, observing and reflecting. Every cycle was conducted in three meetings. The following was the explanation about the action research results.

Based on the result of the students' writing in the cycle1, there was a little improvement of the students average score from pre-test to post-test in cycle 1. The total score of the pre-test was 686 and the average score was 49. The total score of post-test 1 was 896 and the average score was 64 . The result of the posttest cycle 2 was 15 point or $30.6 \%$ higher than the result of the post test cycle 1 . In this second cycle, the students showed better improvement.

Based the analyzing the data by observing and evaluating the result of the students writing product showed $30.6 \%$ of the students who got the score above the Minimum Criteria Completeness (Kriteria Ketuntasan Minimal). From the data above, the researcher concluded that the implementation of the scaffolding technique has not given satisfied result of the improvement students' writing skill. Most of the students have not achieved the Minimum Criteria Achievement. Therefore, this implementation needs to be revised before implementation of the next cycle. So that it could achieve the standard of the score.

The result of posttest 2 showed that the average of the score derived 75.9. Whereas 11 students who passed Minimum Criteria Completeness (Kriteria Ketuntasan Minimal) 67 (sixty seven). From the result of the students' writing in the second cycle, there was better improvement of the students'average score from post-test in cycle 1 to post-test in cycle 2 . The total score of the post-test in cycle 1 was 896 and the average score was 64. The total score of the post-test in cycle 2 was 1063 and the average score was 75.9. The result of the post- test cycle 2 was 11.9 point or $18.6 \%$ higher than the result of the post-test cycle 1 . In this second cycle, the students showed better improvement.

Based the analyzing the data by observing and evaluating the result of the students writing product, the researcher conclude that the numbers of students who passed the Minimum Criteria Completeness Kriteria Ketuntasan Minimal (KKM) alsoincreases from the pre-test and each cycle. In the pre-test there 
were only two students or $14.3 \%$ of the studentswho achieved the score of Minimum Criteria Completeness Kriteria Ketuntasan Minimal (KKM). In the first cycle there were only seven students or $50 \%$ of the studentswho achieved the score of Minimum Criteria Completeness Kriteria Ketuntasan Minimal (KKM). In the second cycle the students who passed the score of Minimum Criteria Completeness Kriteria Ketuntasan Minimal (KKM) were eleven students or $78.6 \%$. It provided that the target of the standard criterion of success in which minimum $75 \%$ of the students passed of the Minimum Criteria Completeness Kriteria Ketuntasan Minimal (KKM) could be achieved. So the researcher and the collaborator decided to stop the action.

The researcher was conducting two cycles to improve the students writing skill. Each of cycle was done by doing test. These are the result of the pre-test, post-test cycle 1 and post-test cycle 2 .

1) The result of the students' average score in pre-test is :

$M=\frac{\sum X}{N}=\frac{686}{14}=49$

2) The result of the students' average score in post-test cycle one is:

$M=\frac{\sum X}{N}=\frac{896}{14}=64$

3) The result of the students' average score in post-test cycle two is:

$M=\frac{\sum X}{N}=\frac{1063}{14}=75.9$

The progress of students' score in each cycle can be seen on this chart below: 


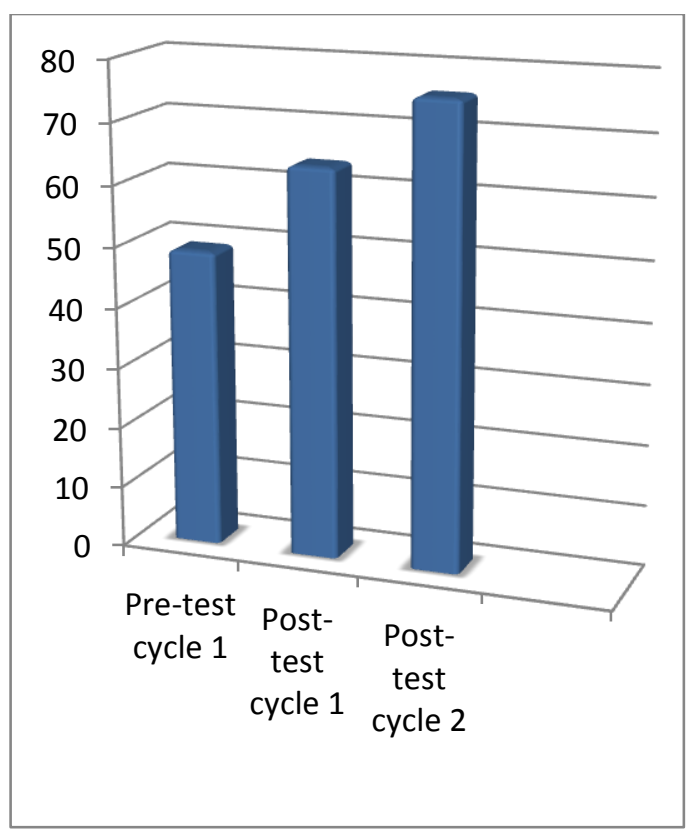

Chart of the students' average score

Based on the chart, it can be showed that the teaching learning process of writing by using scaffolding technique was an effective technique to improve the students' writing skill. The average score of pre-test was 49 , the average score of post-test cycle 1 was 64 , and the average score of post-test cycle 2 was 75,9 .

The students felt easier in writing descriptive text by using scaffolding technique. They also looked motivated and confident in writing learning process. Considering the data above, the researcher concluded that the research was successful. The improvement of students' ability in writing descriptive text can be supported by the improvement of the students' score. The use of scaffolding technique in teaching writing can overcome the research problem that is how to improve the students' writing skill.

The progress of the students' writing score who passed the minimum criteria completeness (KKM) can be seen on this chart below: 


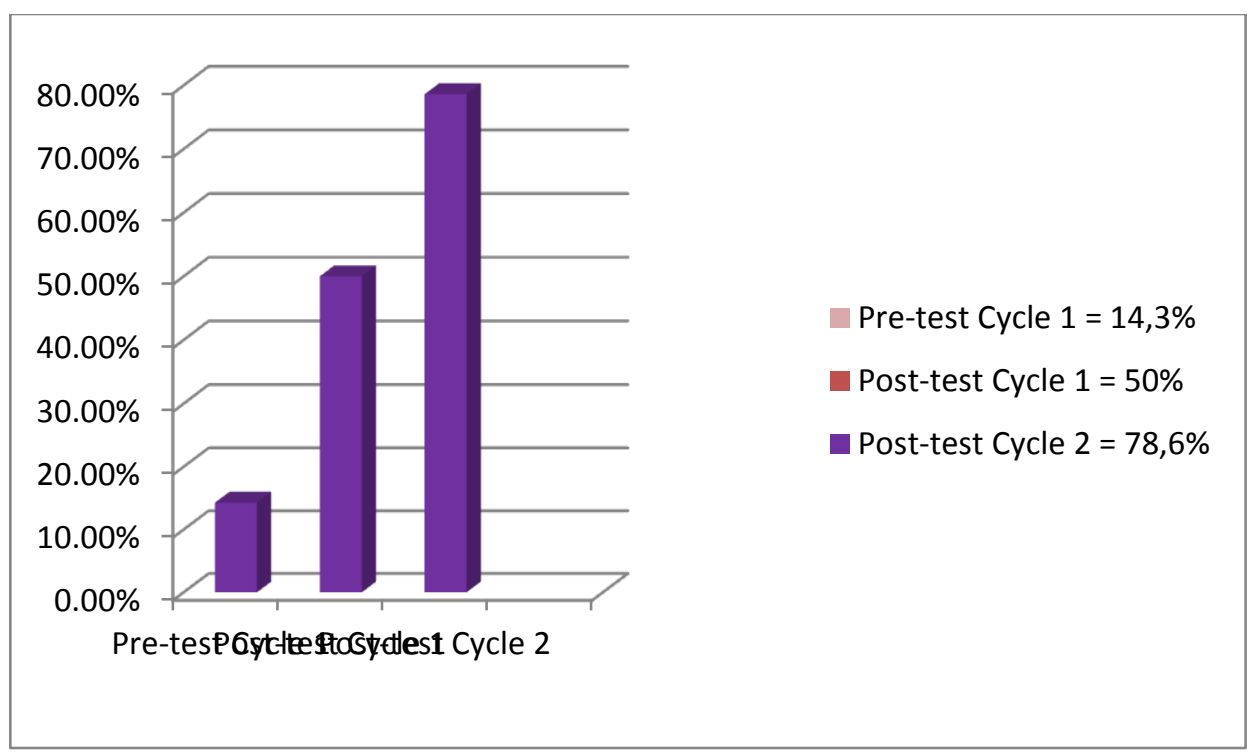

\section{Chart of students' writing score who passed the minimum criteria completeness (KKM)}

Based on the chart, the result of the students' writing who passed the minimum criteria completeness (KKM) was gradually improving. It was showed that there was a good impact of the scaffolding technique toward the increasing of students' ability in writing descriptive text.

The students' writing score who passed the minimum criteria completeness (KKM) in the pre-test was two students or $14,3 \%$. The students' writing score who passed the minimum criteria completeness (KKM) in the post-test cycle 1 was seven students or $50 \%$. The students' writing score who passed the minimum criteria completeness (KKM) in the post-test cycle 2 was eleven students or 78,6\%.

The progress of the students' improvement score can be seen on this chart below:

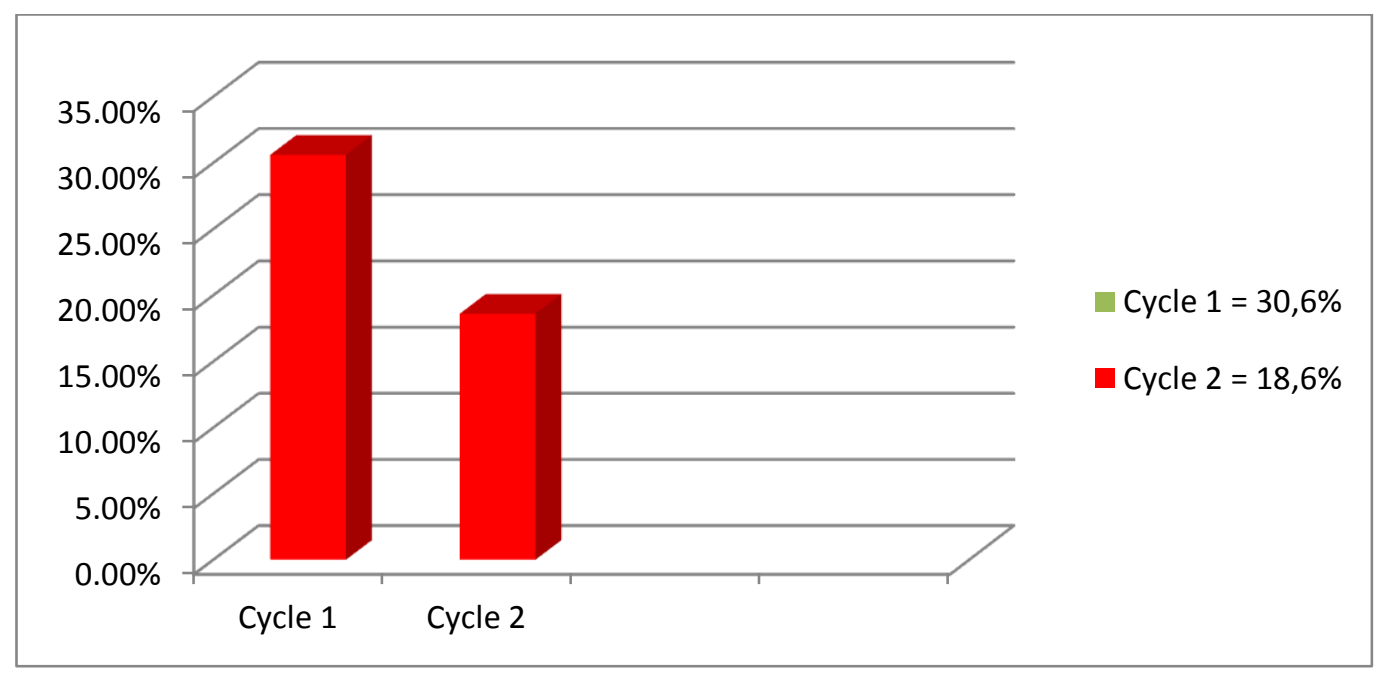




\section{Chart of the students' improvement score}

The chart showed the students' improvement score. The students' improvement score between pre-test and cycle one showed in percentage was 30,6\%. The students' improvement score between cycle one and cycle two showed in percentage was $18,6 \%$. Even though the improvement score of cycle one was higher than cycle two, the researcher concluded that the students were able to improve their writing skill by using the scaffolding technique in each cycle.

Besides conducting two cycles to see the improvement of the student's interest in writing skill by using scaffolding technique, the researcher used the affective descriptive evaluation to obtain a direct a measure of attitude by asking the students to rate an interest of an object (Bloom 1971).

\section{CONCLUSION}

Based implementation, the researcher explained that before the treatment, the students' writing skill was very low. They had problem in mastering vocabulary, paragraph organizing, and sentences structure. Besides, they had less motivated and did not interest in writing. Yet, after she has taught by using scaffolding technique, the students' writing skills was improved. They were able in mastering vocabulary, paragraph organizing and sentences structure. These were the result of the students' improvement writing skill. In pre-test, the students' average score was 49. In post-test of cycle one, the students' average score was 64. It could be described that the result was still under the KKM of 67, and the students were still difficulty in writing. Therefore, it should be improved immediately. In this case the researcher conducted the next cycle of improvement students' writing skill by using scaffolding technique. In the post test of cycle two, the students' average score was 75.9. It meant that there was a progress of the students' writing skill by using scaffolding technique. The result of post-test in cycle two was higher than KKM of 67 , so the researcher decided to finish the cycles.

The result of the students' interest in writing skill by using scaffolding technique was $70 \%$. The researcher interpreted that the students were interested and motivated in learning writing of descriptive text through scaffolding technique. They also understood and did the material easily. So teaching writing skill by using scaffolding technique was appropriate and effective teaching technique, especially for the seventh grade students of SMP BOPKRI Godean.

\section{REFERENCES}

Alibali, M 2006. Does visual scaffolding facilitate students' mathematics learning? Evidence from early algebra. Available at http://ies.ed.gov/funding/grant search/ details.asp?ID=54. Retreived on $5^{\text {th }}$ September 2016

Alwasilah, C. 2005. Peningkatan penggunaan bahasa ilmiah dalam membangun budayamenulis. In Wiedarti (Ed.), Menuju budaya menulis (pp. 3-7). Yogyakarta: Tiara Wacana.

Arikunto, Suharsimi. 2010. Prosedur Penelitian :Suatu pendekatan Praktek. Jakarta: Rineka Cipta 
Badan Standar Nasional Pendidikan (BSNP). 2013. Kurikulum Satuan Pendidikan: Kompetensi Inti dan Kompetensi Dasar Mata Pelajaran Bahasa Inggris Sekolah Menengah Pertama. Jakarta: Depdiknas

Brown, H. Douglas. 2000. Principles of Language Learning and Teaching. NewYork: Pearson Education. (a). 2001. Teaching by Principles: An Interactive Approach toLanguage Pedagogy. Second Edition. White Plains, New York : Pearson Education

(b). 2004. Language Assessment; Principles and Classroom Practices. United States of America: Longman.

(c). 2007. Principles of Language Learning and Teaching (Fifth Edition). New York: Pearson Education.

Burns, Anne. 2010. Doing Action Research in English Language Teaching. New York: Routledge.

Cameron,Lynne. 2003. Challenges for ELT from the expansion in teaching children. ELT Journal Volume 57/2. Oxford University Press.

Evayanti,Improving Reading Comprehension Through Scaffolding Reading Experience (Sre) Strategy of the Seventh Grade Students Of SMPN 1 Kuta Utara. Unpublished thesis:Mahasaraswati Denpasar University. Available at: unmas-library.ac.id/.../ni-putu-eva-yanti-npm-10.8.03.51.31.2.5.

Gallagher,Kelly 2006. Teaching Adolescent Writers. Portland. Stenhouse Publisher.

Graham, Steve and Perin, Dolores. 2007. Writingnext : Effective strategies to Improve Writing of Adolescents in Middle and High schools. New York: Carnegie Corporation

Green, Anna. 2015. Characteristics of Adolescent Social and Emotional Development. Our Everydaylife Journal. Available at http://oureverydaylife.com/5 characteristics-adolescent-social-emotionaldevelopment-4827.html .

Harmer, Jeremy. 2004. How to Teach Writing. England: Longman.

(a) 2001. How to Teach English (2nd ed). England: Longman.

(b). 2007. The Practice of English Language Teaching. 4thed. London: Longman.

(c)_ 2007. How to Teach Writing. Malaysia: Longman.

Hartman, H. 2002. p. 23-69. Scaffolding \& Cooperative Learning. Human Learning and Instruction New York: City College of City University of New York.

Hermayawati et al. 2017. Illustration of the Structured Interview Instrument.

Hogan, K., and Pressley, M. 1997. Scaffolding student learning: Instructional approaches and issues. Cambridge, MA: Brookline Books.

Hutchinson, Tom, and Alan Waters. 2003. English for Specific Purpose.A Learning - Centered Approach. Cambridge: Cambridge University Press 
Hyland, K. 2003. Second language writing. Cambridge: Cambridge University Press.

Kane, Thomas S. 2000. The Oxford Essential Guide to Writing. Berkley Books. Oxford University Press.

Larkin, M. 2002. Using scaffolded instruction to optimize learning. Avaiable at:http://www.vtaide.com/png/ERIC/Scaffolding.htm.

Maier Cassandra, 2011. 5 Characteristics of Adolescence. Available at:http://www.ehow.com/info 8154577 5-characteristics-adolescence.html.

Maslakhah, S. 2005.p. 20-28. Menulis tidak semudah membaca. In Wiedarti (Ed.), Menuju budaya menulis. Yogyakarta: Tiara Wacana.

McKenzie, J. 2000. Scaffolding for Success. [Electronic version] Beyond Technology, Questioning, Research and the Information Literate School Community. Available at:http://fno.org/dec99/scaffold.html.

Meyers, Allan. 2005.Gateway to Academic Writing: Effective Sentences, Paragraph and Essays. New York: Longman.

Nation, 2009. Teaching ESL/EFL Reading and Writing.New York. Routlege.

Nothern Illinois University. 2014. Faculty Development and Instructional Design Center.. Instructional scaffolding to improve learning. Avaiable at http://www.niu.edu/facdev/resources/guide/strategies/instructional_scaffolding to_improve_learning.pdf.Retrieved on October $25^{\text {th }} 2016$

Nunan, David. 2003. Practical English Language Teaching. Boston: McGraw Hill.

(a). 1992. Research Methods in Language Learning. Cambridge : Cambridge University Press.

Olson, J. and Platt, J. 2000. p. 170-197. The Instructional Cycle. Teaching Children and Adolescents with Special Needs. Upper Saddle River, NJ: Prentice-Hall, Inc.

Oshima, A. \& Hogue, A. 2007. Introduction to Academic Writing (3rd Edition). New York. Pearson education,Inc.

Prabandari,Wahyu, Nita. 2015. A Study On Teaching Writing Of Descriptive Text Byusing ScaffoldingTo The Tenth Grade Studentsat SMAN1 Ngadiluwih In Academic Year 2014/2015.University Of Nusantara PGRI Kediri. Jawa Timur. Avaliableat:simki.unpkediri.ac.id/../file.../11.1.01.08.0212.pdf.

Purwanti, Dian, Ndaru. 2010.The Use Of Scaffolding Instruction In The Teaching of Writing At Smp Negeri 17 Malang.Jawa Timur. Unpublished thesis: State University of Malang.Availableat:library.um.ac.id/free contents/savedocpub.php/gri.doc.

Rahmawati, The Use of Scaffolding Talk Technique to Improve Students' Speaking Skill.Unpublished thesis :Classroom Action Research Of The Seventh Grade Students Of Mts Negeri Andong. Salatiga. 
State Institute for Islamic Studies (Stain). Available

at:http://perpus.iainsalatiga.ac.id/docfiles/fulltext/9724543369.pdf.

Raymond, E. 2000. Cognitive Characteristics. Learners with Mild Disabilities.

Needham Heights, MA: Allyn \& Bacon, A Pearson Education Company.

Read, Silvia.2010. A Model for Scaffolding Writing Instructionn: IMSCI, The Reading Teacher. Utah State University

Richards, Jack and Rodgers, Theodore S. 2001. Approach and Method in Language Teaching. Cambridge: Cambridge University Press.

Richard,J. C. 2002. Methodology in Laguage Teaching. An Anthology of Current Practice. New York: Cambridge University Press.

Richards, J. C.and W. A. Renandya. 2002. Methodology in Language Teaching:

An Anthology of Current Practice. Cambridge: Cambridge UniversityPress.

Rumisek, L.A. and Zemach, D. E. 2005. Academic Writing: from Paragraph to Essay. Oxford: Macmillan Publisher

Sawyer, R. Keith. 2006. The Cambridge Handbook of the Learning Sciences. New York: Cambridge University Press.

Spratt, M., Pulverness, A., \& Williams, M. 2005. The TKT course. Cambridge: Cambridge University Press.

Van Lier, L. 2004. The ecology and semiotic of language learning: A sociocultural perspective. New York: Kluwer Academic Publishers.

Vygotsky, L. S. 1978. Mind in Society: the Development of Higher Psychological Processes. Cambridge, MA: Harvard University Press.

(a). 1978. Interaction between learning and development (M. Lopez-Morillas, Trans). In M. Cole, V. John-Steiner, S. Scribner, \& E. Souberman (Eds.),Mind in society: The development of higher psychological processes(pp.79-91).Cambridge, MA: Harvard University Press.

Weigle, Sara Cushing. 2002. Assessing Writing. Cambridge: Cambridge University Press.

Ur, Penny. 2009. A Course in Language Teaching. Cambridge: Cambridge University Press. 